\title{
A SPECIES OF UROCERUS FROM BALTIC AMBER.
}

\author{
By Charles T. Brues.
}

Bussey Institution, Harvard University.

In a large collection of parasitic Hymenoptera of oligocene age imbedded in Baltic Amber recently received from the Geological Institute of the University of Königsberg there is a single fine specimen of wood-wasp referable to the genus Urocerus. As very few fossil Siricidæ have been described and as the family is of particular interest on account of its early known occurrence in the upper Jurassic, this species is described below.

\section{Urocerus klebsi sp. nov. (Fig. 1.)}

$\sigma^{7}$. Length $16 \mathrm{~mm}$. A rather well preserved specimen showing the entire fore wing, antennæ, legs and underside of body. Antenæ consisting of 21 segments, reaching to the tip of the second sternite; flagellar joints of quite even length,

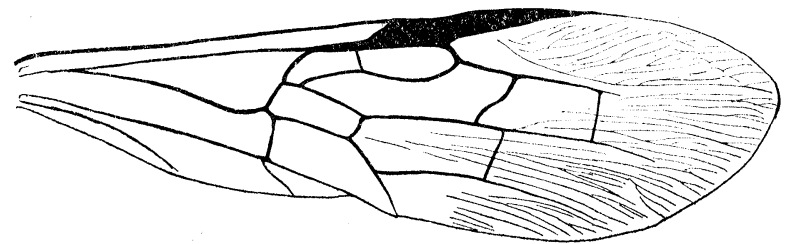

Fig. 1. Urocerus klebsi sp. nov., anterior wing.

gradually more slender to the apex of the antenna; second flagellar joint equal to the first, nearly four times as long as thick. Posterior tibiæ apparently not so distinctly flattened as in the male of Urocerus cressoni Norton, although they cannot be viewed exactly in the lateral aspect; with two short subequal apical spurs and with two series of small bristles below, one along each edge. Anterior wing (Fig. 1) typical for the genus; first transverse cubitus with its lower end bent sharply downward and entering the first discoidal cell at the basal fourth; second section of radius fully two-thirds as long as the third and twice as long 
as the first; submedian cell very little longer than the median; externomedian vein bent downward near apex, but entirely without any stump of a vein; second recurrent nervure entering the third cubital cell before its basal third; transverse lanceolate vein obscured at its base, but apparently arising just before the lower end of the transverse median vein. The apex of the abdomen has been removed in polishing the amber and cannot be described.

Type in the collection of the Geologisches Institut of the Univ rsity of Königsberg

This species differs from the European $U$. gigas and the North American $U$. albicornis, californicus and cressoni by the insertion of the first transverse cubitus on the upper side of the discoidal cell instead of on the basal vein. The one other North American species, $U$. taxodii Ashm. is not in my collection, but Bradley has published a good figure (Pomona Journ. Entom., vol. 5, p. 31) which shows the amber species to resemble taxodii in this respect. The second section of the radius is proportionately much longer than in any of the above-mentioned living species except $U$. cressoni where it is as long as the third.

I have named this species in honor of Professor Klebs who first reported the occurrence of Siricidæ in amber. Klebs (Tagbl. Naturforschervers., vol.62, p. 269) in 1889 referred Baltic amber specimens to Sirex, a closcly similar genus. Quite probab.y the present species may be the same form.

S.rex has been reported from the miocene beds of Radoboj. This was described by Heer as "Urocerites", but later referred to Paururus by Konow (Wiener Entom. Zeit., vol. 17, p. 87, 1898). The name Paururus is now replaced by Sirex. To judge from Heer's figure the posterior tibiæ and their metatarsi are flattened much as in the peculiar Cuban genus 'Teredon and I cannot be satisfied that Konow's reference is correct although of course the males of other genera show a tendency in this direction and Heer's specimen is probably a male; unfortunately the antennæ of "Urocerites" were not preserved, so that there is no indication whether they were of the peculiar type of those of Teredon. Heer has restored them in one figure, but entirely on the basis of those of Sirex and Urocerus. 

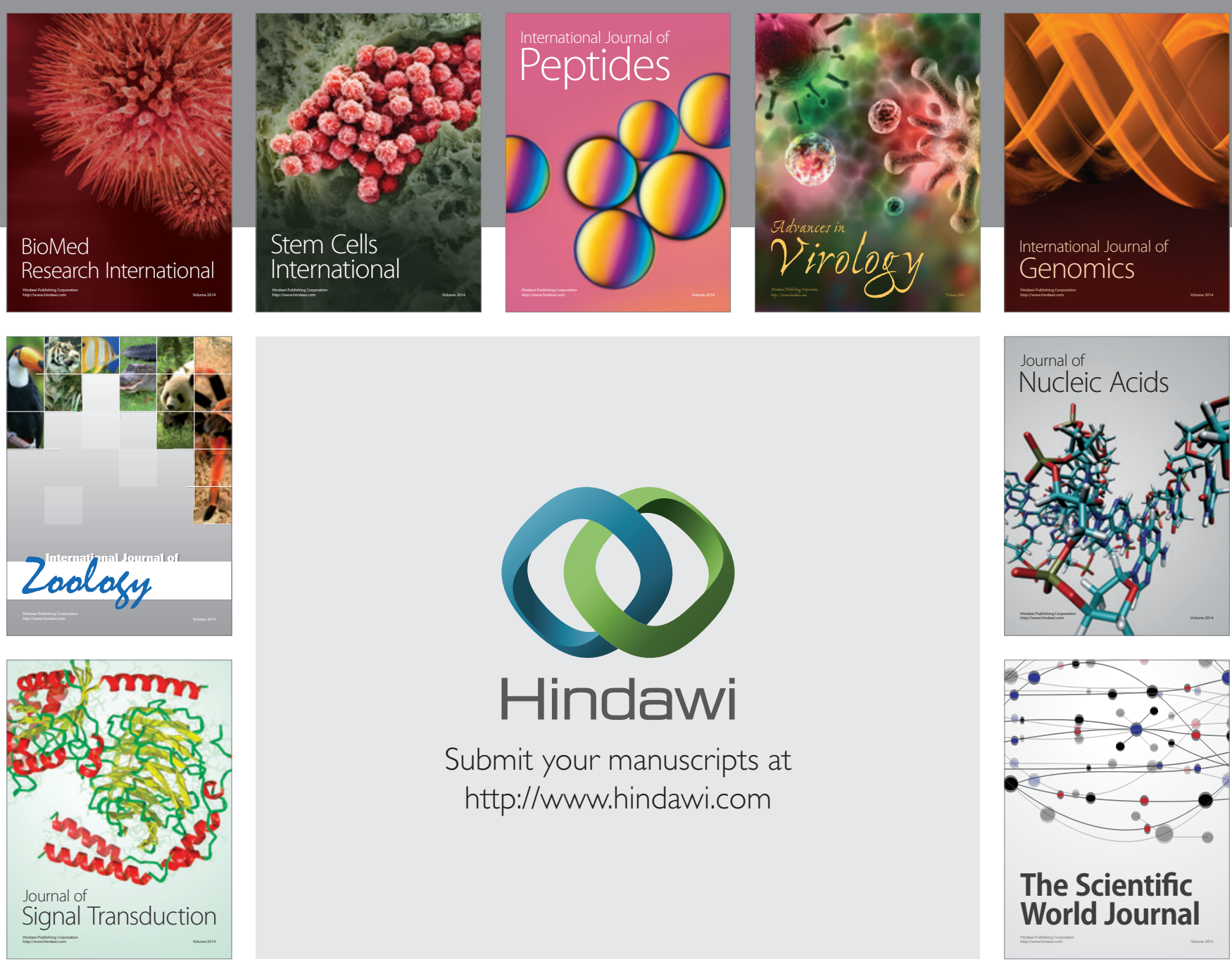

Submit your manuscripts at

http://www.hindawi.com
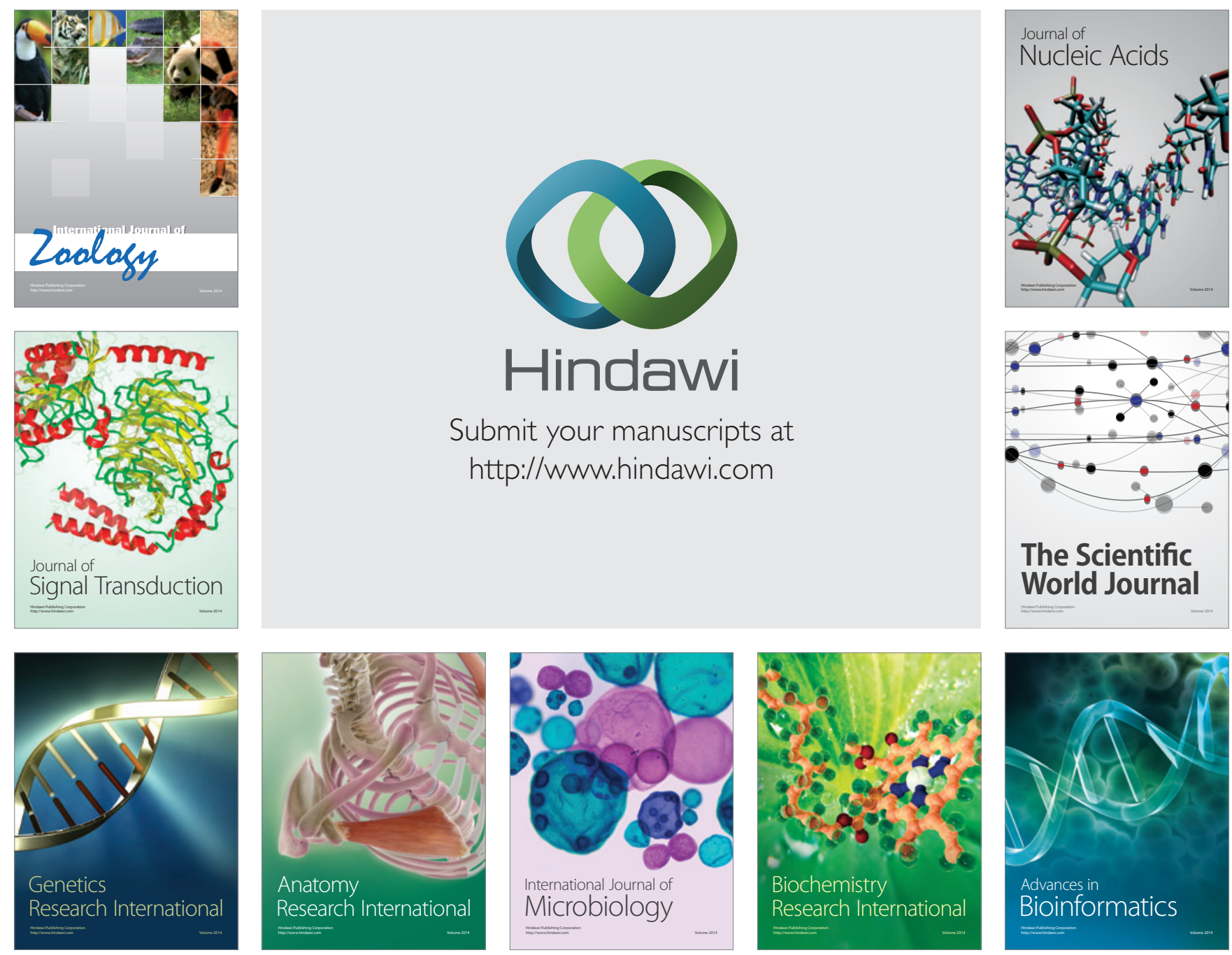

The Scientific World Journal
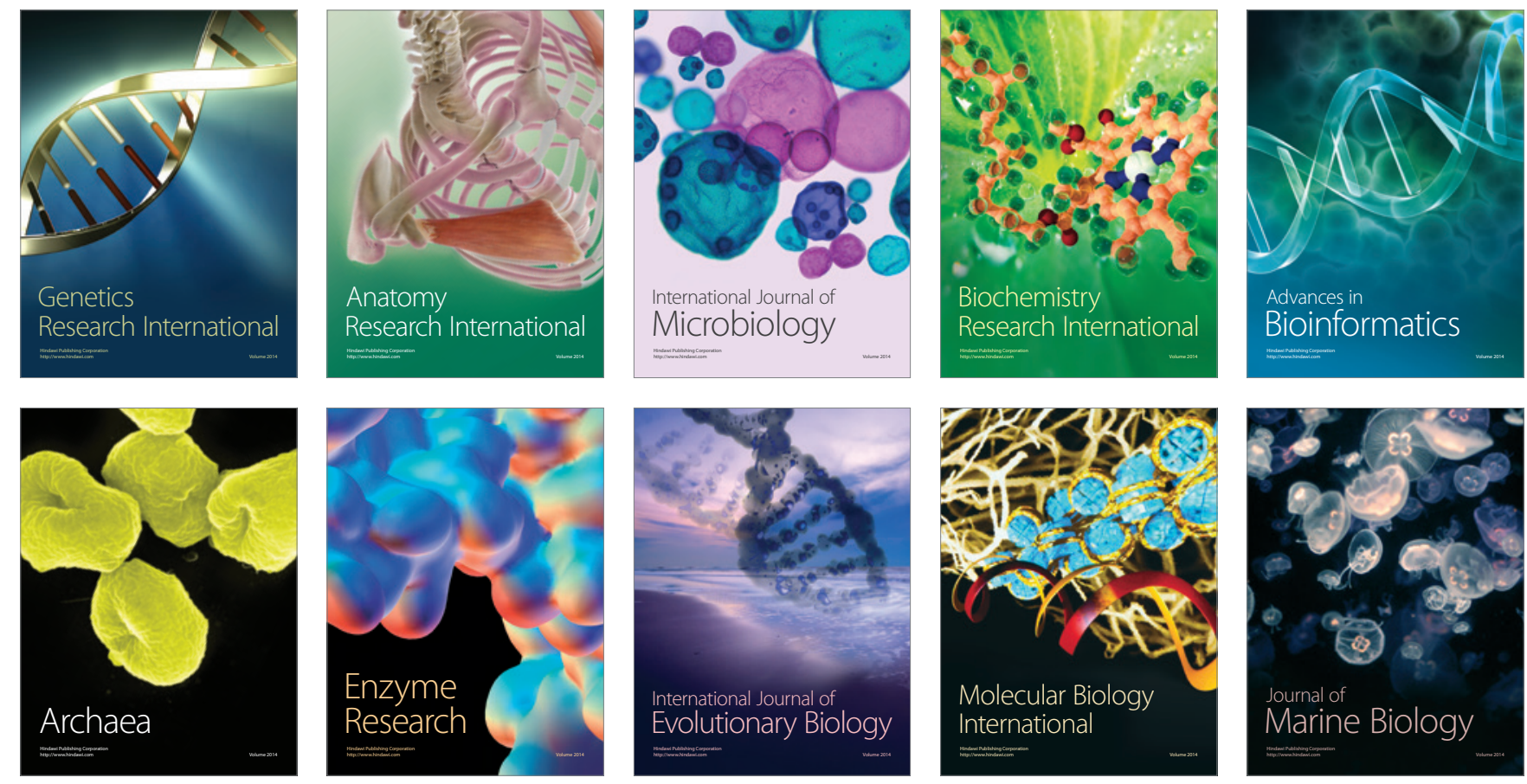